\title{
Sağlık Yapıları İç Mekan Tasarımı: Kuram ve Uygulama Pratikleri Bağlamında Tartışma
}

\author{
Elif ÖZGEN ${ }^{1 *}$
}

Öz

Mekan tasarımı; zihindeki imgenin gerçeklik kazanmasını mümkün kılarak, sanat ve bilim ortaklığından beslenen bir araştırma sahasıdır. Mekanın üretimine ilişkin yapının işlevi, kullanıcı tür ve ihtiyaçları, estetik gereksinimleri gibi pek çok parametre ile tasarım yaklaşımı belirlenmektedir. Sağlık yapıları da; konut, ofis, devlet binaları gibi diğer mekan işlevlerinden gereksinimlerinin farklılaşması sebebiyle ayrılmaktadır. Belirtilen ayrışmanın temel sebebi ise, tıbbi uygulama için mekânsal ihtiyaçların zorunluluk halini almasıdır. Teorik olarak, hastane iç mekanlarına ilişkin çalışmalar, sağlık sektörünün büyük ve devamlı suretle yenilikler ve değişimler içermesi sebebiyle de son dönemde önemli ölçüde artış göstermektedir. Günümüzde iç mekan tasarımının özelleşmiş bir çalışma sahası olarak "sağlık tasarımı" konusu; yeni araştırmalar ve teknolojik gelişmeler ile üretilen yeni malzemelerin kullanımı ile araştırmacılara zemin hazırlamaktadır. Çalışma konusu; teorik olarak "sağlık yapıları iç mekan tasarımı" bilgisinin, pratikte kazanım olarak kullanıcıya nasıl ulaştığının sorgulanmasına ilişkindir. Çalışma sahası ise; araştırma içeriğine daha çok katkı sunacağı düşünülerek herhangi bir özel alan seçilmekten kaçınılarak, ortak olarak kullanılabilecek hastane iç mekanları olarak belirlenmiştir. İncelemede nitel araştırma yöntemi ile karşılaştırmalı anlatımdan faydalanılarak betimsel analizden faydalanılmıştır. Çalışmanın sağlık ve iç mekan tasarımı alanları için; kuram, kullanıcı ve uygulama biçimleri konusunda duyarlılığı artırmaya yönelik katkı sağlaması amaçlanmaktadır.

Anahtar Kelimeler: Tasarım ve Kuram, Kuram ve Uygulama, Sağıı Tasarımı, Mekan ve Kullanıcı, İç Mekan Tasarımı

\section{Interior Design for Healthcare Facilities: A Discussion on Theory and Architectural Practices}

\begin{abstract}
Interior design is a field of research which is nourished from the association between arts and science by enabling the image in mind that will come to life. The design approach is being identified through a number of parameters such as the function of a building regarding the creation of place, the type of users and their needs and aesthetic requirements. Healthcare facilities have also been segregated from other functions of places such as homes, offices, or state buildings. The major reason why such a been on the rise recently because healthcare sector includes extensive changes and specialized in interior design establishes the ground for researchers on the use of new materials manufactured with research and technological improvements. The subject of this study theoretically pertains to question how the knowledge of "interior design for healthcare facilities" reaches to the user as a benefit in practice. On the other hand, the field of study has been determined as hospital interior spaces considering the fact that

\footnotetext{
${ }^{1}$ Hacettepe Üniversitesi, Güzel Sanatlar Fakültesi, İç Mimarlık ve Çevre Tasarımı Anabilim Dalı, *Igili yazar/Corresponding author: elifozgen@outlook.com, elif.ozgen@ hacettepe.edu.tr Gönderim Tarihi: 11.06 .2020 Kabul Tarihi: 21.12.2020
} segregation occurs is that spatial requirements become obligatory for medical interventions. Theoretically, the studies on hospital interior spaces have significantly continuous innovations. Today, the subject of "healthcare design" as a field of study 
this will contribute more to the research content as opposed to selecting any other specific field. The study has been conducted through qualitative research method by means of descriptive analysis using comparative exposition. The study aims at providing contribution to raise awareness on theory, users, and application styles for the fields of healthcare facilities and interior design.

Keywords: Design and Theory, Theory and Practice, Healthcare Design, Place and User, Interior Design

\section{GíRiş}

Mekan; insan için intiyaç olmanın ötesinde, hem yaşayan hem de yaşatan bütüncül karşılığa sahip bir kavramdır. Mekanın araştırma sahası ise yalnızca mimarlık ve iç mimarlık alanları ile sınırlandırılmamaktadır. Günümüzde toplumbilim, siyaset, iletişim, sanat ve çok daha fazla bilim/sanat dalının inceleme alanları içerisinde yer almaktadır. Mekan, disiplinler ötesi karakteriyle özünde insana kavramsal olarak yakınlık kurmaya yönelik birtakım imgeler sunmaktadır. Mekan kavramı; kişiyi/kişileri örten, koruyan, ait hissettiren, kucaklayan ve benzeri hisleri içeren kimliği ile, insan zihninde bıraktığı tanıdık bir imaj oluşturmaktadır. Bu imaj; kültür, deneyim, eğitim gibi kişisel faktörlerce değişim gösterebilmektedir. Değişim gösterse de zihinde benzeri atmosferi çağrıştıran bu yaklaşım için, insani olarak mekanla bağ kurma işi çift taraflı etkileşime intiyaç duymaktadır. Mekan ve insan arasındaki bağ her ne kadar kişi için başka yakınlık faktörü oluştursa da, mekanın da insana yakınlaşmasına intiyaç duymaktadır.

İnsan ve mekan arasında bağ kurma, asıl odaklanılan tasarım sorunu olarak tasarımcı tarafından merkeze alınarak çalışılabilir. Ya da ikincil veya üçüncül problemler arasında yer alabilir. Başka bir senaryo da ise; odaklanılan tüm tasarım problemleri için bütüncül bir üst başlık olarak görülebilir. Ancak, özellikle sağlık yapıları iç mekanlarına yönelik bu çalışmada, insan-mekan konusunun üzerinde durulmasının başlıca sebebi, bütüncül bir sağlık yaklaşımının hem bedensel hem de ruhsal olarak iyileştirmeyi mecburi kılan karakteridir.

Mekan probleminin ya da ihtiyacının ortaya çıkışıyla, tasarımcının karşı karşıya kaldığı birtakım çözülmesi gerekenlerle ilgili liste ortaya çıkmaktadır. Tasarımcının kişisel duyarlılıkları, eğitimi, kültürü vb. parametrelerce değişiklik gösterse de fikir geliştirme, tasarım ve uygulamaya ilişkin basamaklar benzerlik gösterecek şekilde gerçekleşmektedir. Bu anlamda mekan yaratma işinin dinamikleri arasına; gerekli gözlem ve analizlerin gerçekleştirilmesi, kullanıcı özelinde karşılanması gereken ihtiyaçların çözümü, kuramsal bilginin adaptasyonu gibi çok basamaklı bir sürecin içerisinde, tasarımcı çıkış noktaları aramaktadır. Bu noktada fiziksel olarak yapının inşasından önce, zihinsel egzersizler, fikir denemeleri, gözlemler yapılmaktadır. Bu basamakta mekan özelinde teorik alt yapı önemli rol oynamaktadır. Kavramsal süreç ile ilgili bütünsel yaklaşım, özünde çok parçalı ve genellikle belirtilen problemlerin üst üste/dikeyde çözülmesinden çok, yatayda ilişki kurarak çözümlenme eğilimindedir. Yani tasarım problemine ilişkin fikirler ve ihtiyaçlar genel olarak; yapım aşamasına geçene kadar bulmaca parçaları gibi eş zamanlı olarak zihinde birleştirilir. Yapım aşamasında ise kademeli olarak birbirinin üzerine devam eden bir kurguya sahiptir. Kısaca zihinsel tartışmalar da kullanılan teorik bilgilerin devamında yapının inşasına, somut varlığına dair uygulama problemlerine cevap aranmaktadır.

$\mathrm{Bu}$ anlamda mimarlık alanında edinilen mesleki öğretilerin, temelinde eğitim ve sonrasında deneyimleme fırsatı bulunmasıyla başkalaştığını söyleyebiliriz. Öğrenilen, keşfedilen ve kafa yorulan kuramsal bilgi, edinilirken verdiği hazla meslek adayı olarak kişileri beslerken, çalışma hayatıyla beraber tasarımcıyı başka kıyılara sürüklemektedir. 
Belki önceliklerin değişmesi, belki kuramın doğru olarak öğretilip/öğrenilememesi meselesi ile tasarımcının uygulamacı karakterinde değişiklikler ortaya çıkabilmektedir. Sebebi net olmaksızın, hatta sebebin de bir önemi olmaksızın tasarımcının yönelimlerine ilişkin; geçmiş ve şimdi veya geçmiş ve gelecek arasında bağların zayıflama intimali olduğu düşünülmektedir. Bu durumda kuram geçmişi ve öğrenileni tariflerken, şimdi ve gelecek edinilen bilginin üzerine deneyimlenen olarak değerlendirilmektedir. Temelinde normal olarak işleyen bu süreç, eğitim hayatımızda da bizleri bireysel duyarlılıklarımızın başkalaştığı bir dünyaya hazırlamaktadır. Profesyonel hayata geçişle öğretiler gerçeklik kazanmakta ve içeriğinde yeni pek çok problemi bünyesinde barındırmaktadır. Başka bir deyişle, aynı problemler varken gözden kaçırdığımız detaylar kullanılabilir bir mekana dönüşmediği için hata yapma payımız daha kabul edilebilir durumdadır.

İç mekan tasarımı alanında kuram ve uygulama ilişkisine yönelik kesin ve net sınırlar bulunmamaktadır. Aksine eğitim almaksızın yapılan mimari alanında iyi işler, alaylı olarak yetişen bireyler tarafından da mesleki yaşantıda benzer nitelikte uygulamalar bulunabilmektedir. Bu anlamda çalışmanın odaklanılan kısmı tasarımcının duyarlılığı ve mekan yaratım sürecinde yalnızca mekanın ihtiyaçlarına değil, insan ile ilişkisine teknik gereksinimlerle beraber cevap verip veremediğinin tartışılmasıdır. Bu anlamda çalışma bir sanat eseri olarak mekanı tartışma dışı bırakmaktadır. Mekan sorununa, işlev ile beraber pratik edilmiş mekanın kuram ile olan ilişkisi doğrultusunda değinilmektedir. Teori ve uygulamaya ilişkin anlatımın desteklenmesi için ise hastane iç mekanları konu edilerek, bahsi geçen tavır üzerine anlatım pekiştirilmeye çalışılmıştır. Ancak hastane iç mekanları içerisinde yer alan; genel mekanlar, hasta odaları, cerrahi birimler, tedavi alanları gibi iç mekanların her birinin ayrı tasarım intiyaçları olması sebebi ile alan belirtmekten kaçınılmıştır. Bu yolla mekânsal gerekliliklerin sorgulanması ihtiyacı başka bir çalışma konusu olarak değerlendirilerek, teori ve pratik mekânsal sorgulamalara ilişkin daha doğrudan bir yaklaşım oluşturulmaya çalışılmıştır.

\section{MEKAN MESELESi}

Mekanın tartışmasını mümkün kılmak için öncelikli olarak kavramın tanımını yapmak gerekmektedir. Bu anlamda "mekan" kavramını yalnızca mimarlık ve mimarlıkla ilişkili alanların özelinde değerlendirmek doğru bir yaklaşımı içermemektedir. "Mekan" kelimesinin zihindeki algısı gibi, mekanın çalışma alanı da; kesiştiren ve kapsayıcı niteliktedir. Bu durum doğal ve besleyicidir. "Mekan" iyileştirici ve sonsuz bir problem konusu haline getirmeye katkı sunacak nitelikte değerlendirilmektedir.

Bu noktada mekan; TDK ${ }^{1}$ için; bulunan yeri tariflerken, Mimar Hasol için, insanı çevreden belli bir ölçüde ayıran ve içinde eylemlerini sürdürmesine elverişli boşluk (Hasol, 2008:313), Mimar Sözen ve Tanyeli için ise uzayı sınırlandırılmış parçası, mimari bir ürünün dördüncü boyutu olarak tanımlanmıştır (Sözen ve Tanyeli, 2018:203). İç Mimar Özkan'a göre; insan hareket ve davranışlarına yönelik olarak düzenlenmiş bir çevre olarak görülmektedir. Mekan tanımı; Filozof Heidegger tarafından mekânı saf yapı olarak görme eğilimini dönüştürmüş ve mekânı bir etkileşim ve deneyim yeri olarak kabul edilmektedir. Ayrıca Sosyolog Lefebvre'e göre ise, mekân, ne ideoloji veya politikadan ayrıştırılabilecek bilimsel bir nesne, ne bir özne ne de sadece sosyal ilişkilerin ve eylemlerin basit bir sahnesi değildir. Mekân, bir şey değil ancak şeyler arasındaki ilişkinin bir kuruluşudur, toplumsal olarak üretilir ve toplumsal faaliyetin ürünüdür (Lefebvre,1995:3-6). 
Bütüncül bir yaklaşımda; mekan kavramının döneme, kişisel deneyimlere, alan çalışmasının içeriğine göre birbirinden farklı yaklaşımlarda ortaya konulduğu, tanımlandığı ve anlamlandırıldığı görülmektedir. Mekanın, insanlığın başlangıcında henüz bir kavram olarak var olmasa da insan ile beraber var olduğu söylenebilir. Çünkü barınma intiyacının karşılığı, mekanın ta kendisini tariflemektedir. Zamanla temel intiyaçlar değişiklik göstererek başka birtakım sorunların, intiyaçların karşılandığı bir biçimlenişe evrilmiştir. İnsanoğlunun gelişim sürecinde ve toplumu etkileyen değişimlerde mekan kavramı, kurgusu, yapısı ve kullanılan malzemeler ile değişimlere paralel olarak biçimlenmiştir. Bu değişimlerin mekanın tasarımı konusunda da, çağın gerekliliği olan yaklaşım ve yöntemlerle yorumlandığı görülmektedir (Kaptan, 2003:1). Bir başka deyişle çalışmanın içeriğini oluşturan kuram-pratik devamlı olarak değişimi içermektedir.

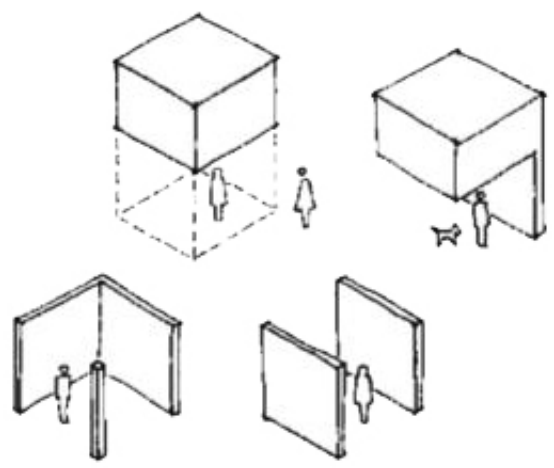

Görsel 1: Mekan denemeleri (Frederick, 2007, s.10).

Genel anlamda iç mekan tasarımına ilişkin senaryoya bakıldığında eğitim ile başlayan kuramsal süreç, zaman içinde uzmanlaşma eğilimi ile (hem kuramsal hem de pratik anlamında ya da her ikisi bir arada) yaşayan bir mekan oluşturma çabası ile sonuçlanır. Mekanın yapı inşasının tamamlanması ile kullanıcıya teslim edilen mekan için, tasarımcının sorumluluğu sona ermektedir ve önemli bir problemle karşılaşılmadığı sürece tasarımcı tarafından bitmiş bir işi tanımlamaktadır. Sürecin başlangıcı olan eğitim ise; ülkelere, toplumlara, yaklaşımlara, yerel değerlere... göre değişkenlik göstermektedir. Bu anlamda toplumların genel niteliklerini oluşturan değişkenler eğitim yoluyla tasarımcıya, tasarımcı yorumuyla yeniden topluma sunulmaktadır. Belirtilen döngü, var etmenin yeterli olmayacağının altını çizecek niteliktedir. Gereksinimlerini doğru şekilde gerçekleştirememiş mekan yalnızca var olabilir, yaşatamaz dolayısı ile de yaşayamaz. Noksan bir varoluş tatmin edici olmaktan çok uzaktadır. Bielefeld ve Khouli (2011:9)'nin de belirttiği gibi; mimarlık boşlukta yaratılamaz. Çoğu bina, inşa edilip gerçeklik kazandığı bağlama verilmiş bir yanıttır. Mimarlıktan işlev görmesi, bir tasarım problemine somut çözüm getirmesi, tasarım ve malzemelere hayat vermesi de beklenmektedir.

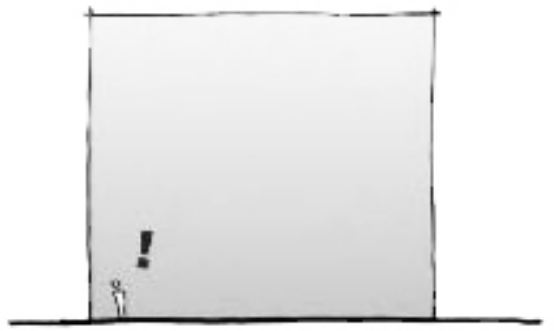

Görsel 2: Mimari tasarımı insan-mekan ilişkisine eleştirel bir bakış (Frederick, 2007, s.65).

Çalışma özelinde "mekan" iç mekan tasarımcısının gözünden değerlendirmeye alınması sebebiyle bu tasarım alanındaki yaklaşımlara ilişkin değerlendirmelere yer 
verilmektedir. Tasarım alanının mekan ile birincil ilişkide görülebilecek bir dalı olarak, gereksinimleri belirtilen kapsamda incelenmesi amaçlanmıştır. İnceleme yaklaşımı; kullanıcı, mekan gereksinimleri, kuram ve pratik/uygulama arasında sıkışan tasarımcının rolünü tartışmak ve gerçekleştirilmiş pratikleri üzerinden faydacı bir tutumla değerlendirmesine yöneliktir. Alanın kendi içinde sınırlarının geniş olması sebebi ile "sağılı yapıları" özelinde kapsamı daraltılmıştır.

\section{KURAM VE UYGULAMA}

Bir yapıyı üç boyutlu bir kütle olmaktan çıkaran özellik bir mekana sahip olmasıdır. Yapı onun sayesinde, en, boy ve yüksekliğin ötesinde bireyin devingenliğinden kaynaklanan anlık yaşantılarla edinilen bir mekan boyutu kazanır. Mekan boyutunun kişinin/kişilerin devingenliğinden ötürü, sayısız yaşantılar yaratabilme niteliği mimarlıkta yeni bir boyuttan bahsetmeyi olanaklı kılmaktadır (Sözen ve Tanyeli, 2018:203). Kuram, arazi gereksinimleri ve kullanım intiyacı kapsamında tasarlanan mekan için insan, yalnızca bir nesne niteliği taşır, kuramsal olarak insanla ilişkisine de dikkat çeker ancak bazı projelerde uygulama aşamasında kurgudan sapma yaşanmakta ve odak değişmektedir. Dolayısı ile de mekan da yaşayan/yaşanan "yer" olmaktan çıkmakta ve maddi varlığı ile nesneden ibaret hale gelmektedir.

Başka bir deyişle mimarlıktan; kullanıcı göz ardı edilmeksizin, işlevi/işlevleri karşılaması, bir tasarım problemine somut çözüm getirmesi, tasarım ve malzemelere hayat vermesi beklenmektedir. Bu anlamda yapıdan kullanıcıların ne şekilde yararlandığını veya yararlanmak istediğini, tasarımcının çözümleme süreci içerisinde ele alması, süreç için önemli basamaklardan biri olarak görülmektedir (Görsel 3).

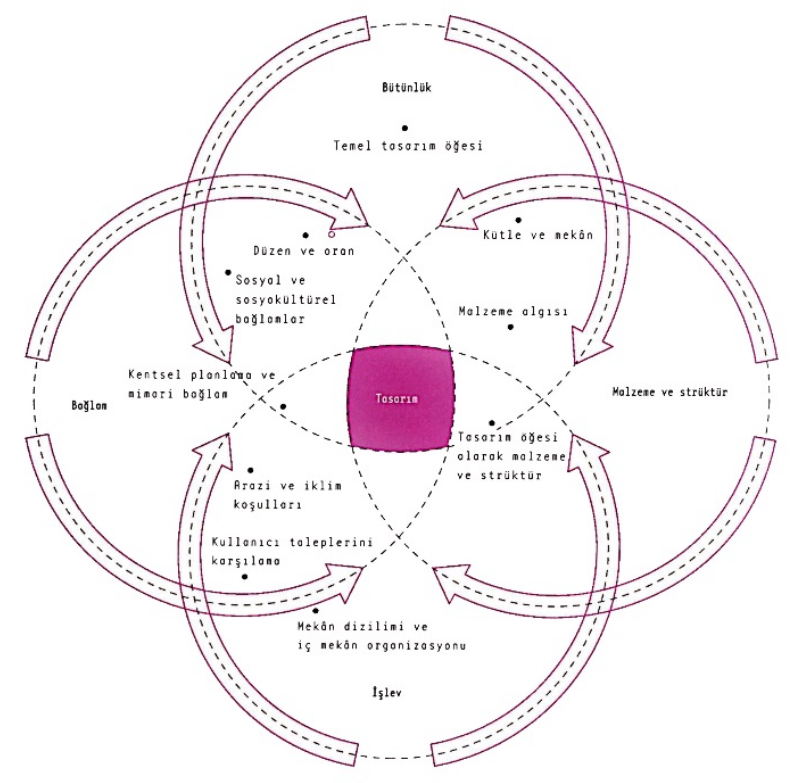

Görsel 3: Tasarım haritası (Bielefeld ve Khouli, 2011:8).

Mimari mekanın kuramsal bilgisi, mekansal olarak uzmanlık (aydınlatma, sürdürülebilirlik vb.) gerektiren pek çok alandan oluşmaktadır. Çalışmanın kapsamında sağlık yapılarına odaklanılsada; iç mekan tasarımına ilişkin kuramsal bilginin genel çerçevede edinilmiş olduğu varsayılarak çalışma gerçekleştirilmiştir.

$\mathrm{Bu}$ anlamda kamusal yapılar grubunda yer alan, sağılı yapıları iç mekan tasarımı özelinde genel yaklaşımın üzerinde durulmasında fayda olacağı düşünülmektedir. 
Kamusal mekanların, temel intiyaçlar kapsamında diğer yapı çeşitlerine kıyasla çok sayıda kullanıcıya yönelik olarak ele alınması gerekmektedir. Hastane yapılarında ise; sağlık hizmeti vermesi sebebi ile insan sirkülasyonunun oldukça dikkate alınması gereken ve intiyacın karşılanmasının zorunlu olduğu temel yapı problemleri yer almaktadır. Yapının mekânsal olarak intiyaçlarının karşılanması ötesinde, çözümlenmesi gereken problemleri de mevcuttur. Bu noktada, teorik olarak insanmekan etkileşimini mümkün kılan hastane iç mekanları yaratma çabası ile teknik gereklilikler bir araya getirilmelidir. Yani, tüm malzemelerin doğru seçildiği, yönetmeliğe uygun olarak yapılandırıldığı bir yaklaşım ile yapının kullanıma hazır olması ayrı değerlerdir. Keşif ve ihale usulünce belirlenen metrajlarla, usulüne uygun malzemenin kullanımı mekanı yalnızca maddesel olarak "var" kılmaktadır. Mekanın asıl meselesi "o"nun nası "var" edileceği ve kullanıcı tarafından deneyimlenebileceğine ilişkindir.

Teorik olarak sağlık yapılarına ilişkin iç mekan tasarım yaklaşımları da yapı tipleri ve intiyaçları gibi uzmanlık alanlarına ayrılmaktadır. Cerrahi işlemlerin gerçekleşeceği, giriş ve danışma ihtiyacının karşılandığı, hasta odası olarak kullanılan odalar gibi birbirinden farklı gereksinimler ile ilgili araştırma alanları özelleşmektedir. Ancak çalışmanın sınırılığı gereğince sağlık yapıları tasarımına ilişkin genel yaklaşımın belirtilmesinde fayda görülmektedir. Sağlık yapılarının tasarımı, yönetmelik ve kılavuzlarla her ülkede başka olsa da, aslında benzer kriterlerle belirlenmektedir. Ülkemiz için yeni yapılacak sağlık yapıları ve mekânsal olarak değişim gerektiren tüm uygulamalar T.C. Sağlık Bakanlığı tarafından düzenlenmiş olan "Türkiye Sağlık Yapıları Asgari Tasarım Standartları 2010 Yılı Kılavuzu"na uygun olarak yapılma zorunluluğu taşımaktadır.

Günümüzde sağlık tasarımı iç mekan alanında; kullanıcı odaklı, kullanıcı sayısı ve gereksinimlerini karşılayacak, hijyenik, uzun süre dayanımlı malzemelerin kullanımını ve doğal kaynakların (gün ışığı, doğa ile etkileşim gibi) desteklenmesini içeren kapsamlı mekansal değerleri içermektedir (Fawcett, 2003, s.10-19). Bu anlamda bekleme koltukları olmayan bir bekleme salonu, tanımlanmış bir bankosu bulunmayan bir kayıt-kabul biriminin varlığının, maddenin varlığını karşılasa dahi mekansal olarak bir varlığı kapsamadığı aşikardır. Çalışma bu noktada, mekansal gereksinimlerin teorik yapısının incelenmesini, verilerin kullanımını ve ihtiyaçların doğru tahlili ile, uygulama aşamasında da maddi varlığın ötesinde, insanla etkileşimi destekleyecek yaklaşımın gerekliliğini savunmaktadır. Yani, bekleme alanı için gerekli mekansal maddelerin varlığının, teorik bilgilerin ve teknik gereksinimlerin kullanımı uygulamanın tamamlanmamış olduğu savını öne sürmektedir (Görsel 4).
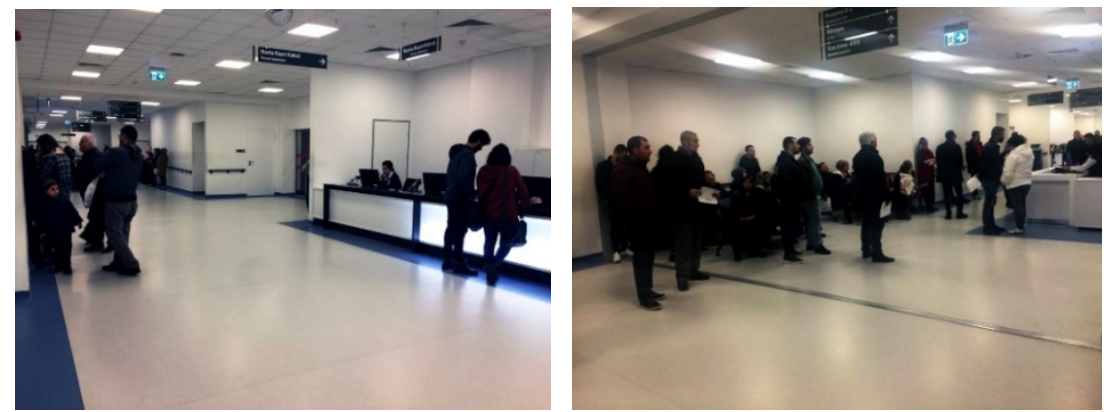

Görsel 4: Ankara'da bir hastane acil birimi, kayıt kabul bankosu ve bekleme alanları (Kişisel Arşiv, 2019). 


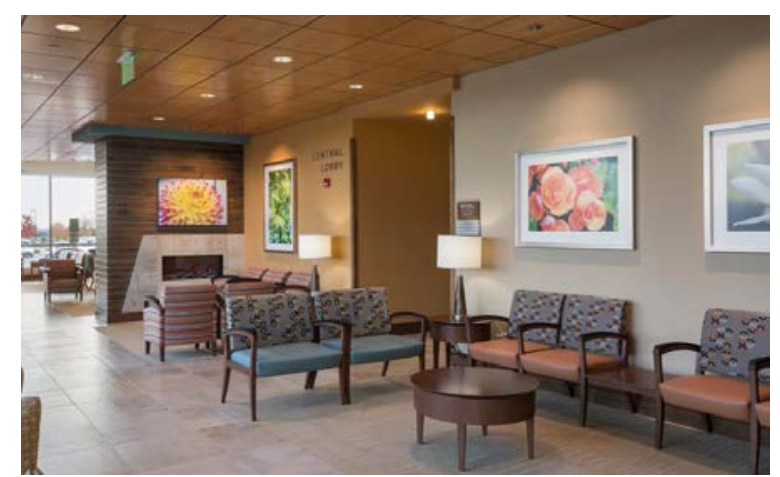

Görsel 5: Kettering Opens Health Clinic Bekleme Alanı(31.000 m2)(URL1).

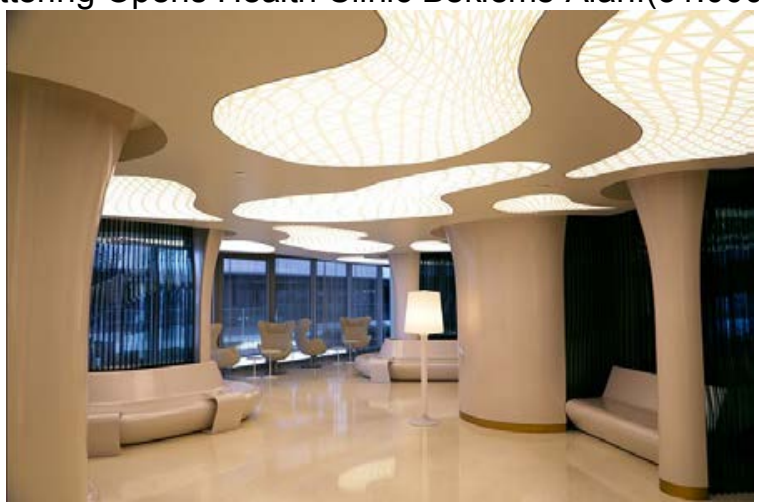

Görsel 6: İstanbul'da özel bir hastane (URL2).

Yukarıda belirtilen örnekler, benzer fonksiyonlar için tasarlanmış mekanların farklı biçimlenişleri sebebi ile seçilmiştir. İlk örnek (Görsel 4); kişinin kullanıcı olduğu gerçeğine odaklanmak yerine, ihtiyaçların odağında tasarlanmıştır. İkinci örnek (Görsel $5)$; evsel bir nitelikle insan odaklı olarak tasarlanmış ve fazlalıklardan arındırılarak optimum bir çözüm olarak karşımıza çıkmaktadır. Son örneğe (Görsel 6) bakıldığında ise; insan odağındaki tasarım anlayışı, sektörleşmiş bir imaj olarak hastane mekanına dair izlenim yaratmaktadır. Gerekliliğinden fazla ve belli bir kesimin hizmetine sunulduğunun ayırt edici olmasının çalışmanın odağında olduğu hissi yaratmaktadır. Bu anlamda 3 bekleme alanı için farklı tasarım anlayışları ve uygulama biçimleri olduğu görülmektedir. Teori ve uygulama ilişkisi içerisinde bu örnekleri birbirinden ayıran en önemli özellik imajıdır. İmajdaki en önemli parametre ise bütçedir. İç mekan tasarımına ilişkin yaklaşımın odağında ise optimum bütçe ile düşünsel olarak doğru tasarlanarak pratik edilmiş bir yaklaşım belirlemenin süreci daha olumlu etkileyeceği düşünülmektedir.

Hastane kullanıcılarının, yaş aralığının geniş olması sebebi ile, tasarım uygulamaları ve duyarlılıkları da geniş bir yelpazeye sahiptir. Bu noktada farklılıkların ve karşılanması gereken intiyaçların tespiti önemlidir. Ancak hastane iç mekanlarının kurgusuna ilişkin öngörülü olmakta fayda vardır. Öngörülen kullanıcı sayısı dahi, bir yerine iki refakatçinin gelmesi ile karşılanması gereken ihtiyacın oranında değişikliğe sebebiyet verebilmektedir.

Bir başka hastane iç mekanı olarak çocuk klinikleri genel mekanları ele alınmaktadır. Çocuk klinik ve hastaneleri antropometri ve psikolojik değerlendirmelerin farklılaşması sebebiyle kendi başına bir çalışma alanıdır. Hastanelerde çocuk kullanıcılar için ayrımış bölümlerin, ergonomi standartlarını sağlaması ve renk kullanımı ile yüzeylerde kullanılan şirin bulunan motiflerin, mekansal olarak fiziksel ve psikolojik gereksinimleri karşıladığının düşünülmesi de, uygulamaya dair genel yaklaşımlardan biri olarak 
belirtilebilir (Görsel 5). Bu özel mekanlarda genellikle bir tasarımcıdan destek alınmasından çok, yaklaşım; yönetimin/sağlık personelinin/birim amirinin problemi analiz etmesinin ardından kullanıma hazır edecek bir taşeron kullanarak mekan intiyacını çözmek üzerine olduğu görülmektedir.
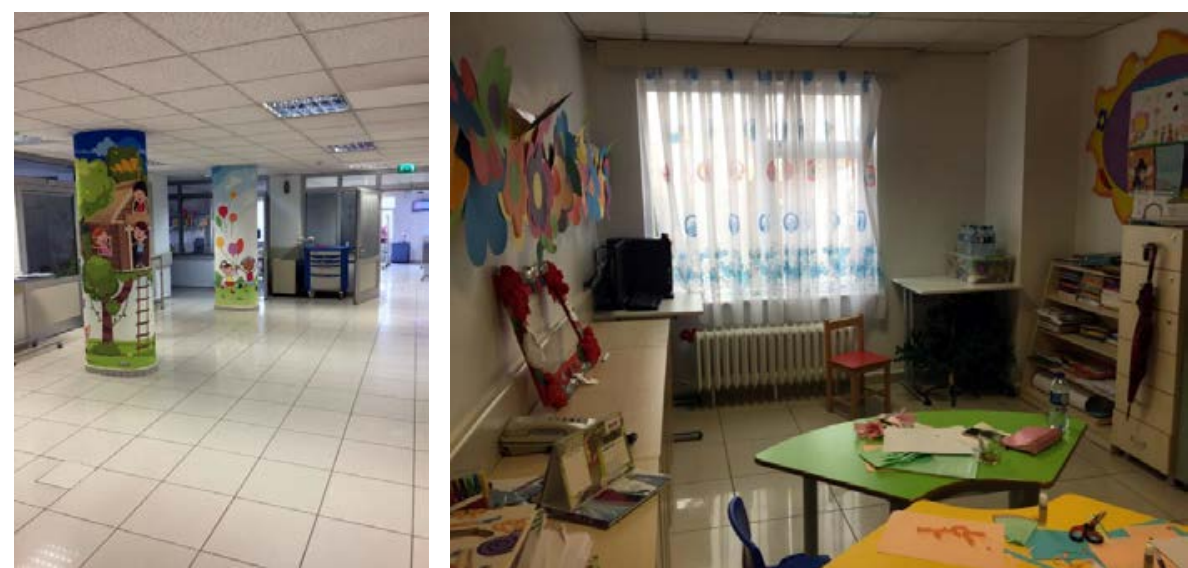

Görsel 7: Ankara'da bir hastane çocuk yatan hasta birimi ve aynı birime ait çocuk oyun odası (Kişisel Arşiv, 2019).

$\mathrm{Bu}$ durum hiç var olmayan bir mekandan elbette daha olumludur. Ancak kaynakların gereksiz kullanımından ibarettir. Hastalara, yakınlarına, hastaneye ve dolayısı ile de topluma faydadan çok zararı dokunduğu, ayrılan zaman, para ve emeğin potansiyelinin çok altında kullanıldığı düşünülmektedir.
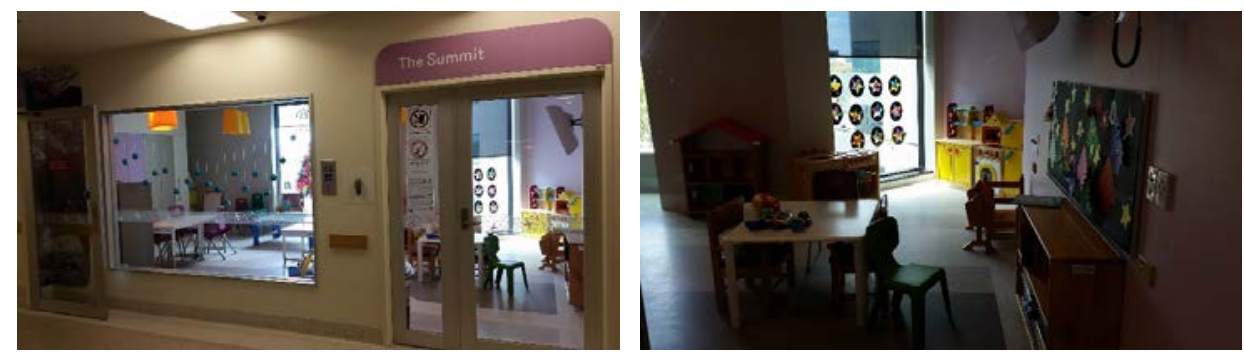

Görsel 8: Royal Children Hospital oyun odası, Avustralya (Kişisel Arşiv,2017).
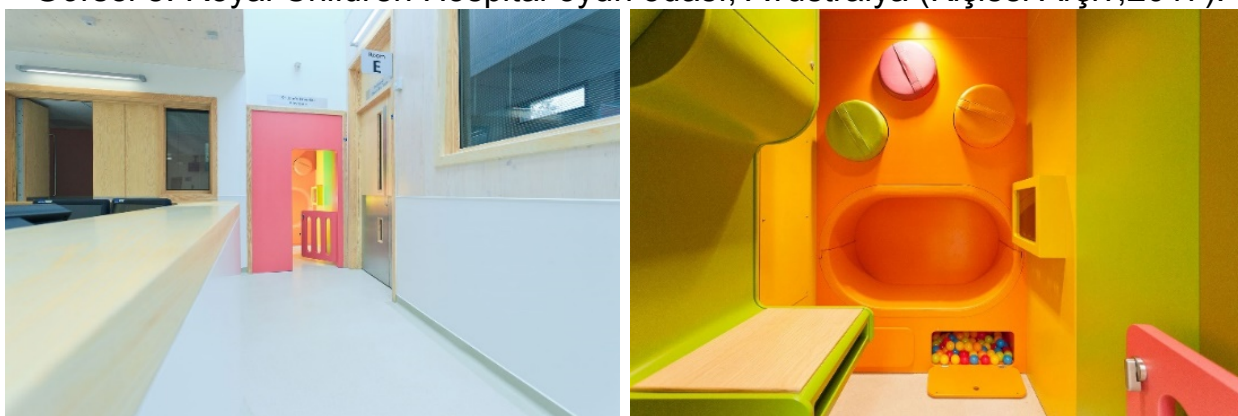

Görsel 9: The Royal United Hospital Neonatal Intensive Care Unit (NICU), İngiltere (URL3).

Belirtilen mekanlar için kullanımı engelleyecek temel bir eksik bulunmamaktadır. Maddesel olarak, kuramsal alt yapı kullanılarak (aykırı bir süreç içerdiği düşünülmektedir) mekanlar kurgulanmıştır.

Çocuk oyun alanları için incelenen üç örnek için de birbirinden farklı odaklarda tasarlandığı söylenebilir. Aynı fonksiyona sahip, tasarım anlamında başkalaşan bu uygulamalar için, tasarımdan beklenen katkı, çocuk için iyileştirici ve yaratıcı bir mekan olarak hasta çocuğa destek sunmasıdır. Örneklerden ilki (Görsel 7); Yüzeylerden oluşan ve renkler ile çocukların sempatisini kazanmayı bekleyen bir çalışmadır. 
Ergonomik olarak kullanım anlamında bir sorun yaratmasa da; çocuk için tasarlanmış olma durumundan çok, mekanın bu amaçla mobilyalar getirilerek oyun odası oluşturulduğu izlenimi mevcuttur. İkinci örnek (Görsel 8); çocukların yaratıcılık düzeyini nispeten senaryolaştırarak oyun kurgulayabileceği araçların varlığı sebebiyle daha olumludur. Son örnekte (Görsel 9) ise; dar bir alanda tasarım gerçekleştirilmese sebebiyle yetersiz, ancak kompakt çözümler anlamında olumlu taraflar taşıyan bir yaklaşıma sahiptir.

\section{SONUÇ VE DEĞERLENDIRME}

Bir deneyi açıklayabilmek, gözlemek, ayrımlarına inerek yeniden birleştirmeye, bir sonuca varmaya çabalamak demektir. Bir yapının toplum deneyi olabilmesi için, önce tanımlanması, eleştirilmesi gerekir. En kötü yapının bile belli kurallar içinde eleştirilerek, niteliklerinin ortaya konulup, yanlış-doğrularının açıklanmasına çalışılması, önceden yön tutmayan yargılarla, o yapının tanımlanması, tartışma konularının açılması, hele bunun bir çevreye duyurulması, toplum ilerlemesinde en yararlı görevler arasındadır (Bektaş, 2001:13). Çalışmanın içeriği Mimar Bektaş'ın da deyimiyle toplum faydası sağlamak üzerinedir. Tasarım kuramı ve uygulaması için keskin sınırlar hem mevcut hem de benzer şekilde mevcut değildir.

Modernin sanatçısı Baudelaire, modern düşünceye göre saf sanatı "Aynı anda hem sanatçının dışındaki dünyayı hem de sanatçının kendisini, nesne ile özneyi içeren, düşündüren bir sihir yaratma çabası" olarak açıklamıştır (Gay, 2017:57-67). Mimarlıkta işte bu yaratma çabasının merkezinde yer almaktadır.

Toplumsal olarak, profesyonelden destek alma konusunda yetersiz bir düzeyde, kendi işimizi kendimiz halledebiliriz mantığı ile pek çok konuya yaklaşmaktayız. Bu konuda iyi olduğumuz konular gecekondular gibi mekânsal denemelerimiz de bulunmaktadır. Ancak mimar, iç mimar veya tasarımcıya ayrılması gereken ödeneğin faydasız bulunduğu genel yaklaşımda, toplam bütçe içerisinde asıl meselenin mekanın yaşaması/yaşatması gereksinimi olduğunu unutulmaktadır. Bir yapı, mekan için, fikir içeren, kuramsal bilgi ve kullanıcı gereksinimlerini içeren bir yaklaşımda yapının yapılması ile, maddesel olarak kullanılır durumda bir mekan yaratımı yaklaşık olarak aynı bedele sahiptir. Fikir, duygu ve zihinsel olgunluk gerektiren asıl parçanın, yani üretme eğilimindeki tasarımcının toplumdaki yerini pekiştirerek ve kuram-uygulama ilişkisini insan-mekan odağında çözecek tasarımcılar yetiştirerek bütüncül bir iyileşme sağlanabileceği düşünülmektedir.

Mekan tasarımının ise; alanında uzmanlaşmış tasarımcı/tasarımcılar tarafından ele alınılması, tasarımcının ise; mekanı yalnızca maddeden ibaret görmediği ve kullanıcı intiyaçlarını doğru analiz ederek, yaşanabilecek bir ortam olarak kurgulaması gerekmektedir. Teorik bilginin, uygulama yapmak için gerekli altyapıyı oluşturmaya katkı sunduğu yadsınamaz bir gerçeklik olarak karşımıza çıkmaktadır. Tasarım için tasarımcının, mekan için ise kullanıcının özne olmaktan nesne olmaya doğru değişim gösterdiği gözlemlenmektedir. Bu sebeple tasarımcıya, mimara toplumsal iyileşme için önemli roller düşmektedir. Bu anlamda;

- Parçası olunan kültürü öğrenmek ve yaklaşımlarını keşfetmek

- Profesyonel olanla (kamu/kuruluş/firma/kişi) çalışmak

- İyi bir okur, çizer ve gözlemci olmak

- Deneyimleri kullanmak

- Yapıyı yaşayan bir mekan olarak var etme çabası taşımak

- Faydacı bir yön belirlemek

- Tasarım eğitimi konusunda duyarlılıkları paylaşmak 
- Tasarım eğitiminde pratik, uygulama sahaları sunmak

- Kendimizle (tasarımcı) beraber kullanıcının da özne olduğunu unutmamak... gibi öncelikleri geliştirme çabasının kişilerden başlayarak toplumda önemli değişimlere imkan tanıyacağı ön görülmektedir.

Çalışma özelinde ise; yapılan 2 örnek genel mekan çözümüne ilişkin, gerekli mekânsal tüm elemanların kullanıldığı görülmektedir. Yani maddesel olarak ihtiyaç duyulan her şeye sahip alternatifler üzerinde durulmuştur. Ancak farklı duyarlılıkları ve tasarım fikirleri ile birbirinden farklı nasıl uygulamalar yapılabileceği üzerinde durulmuştur. Farklılaşmayı göstererek aslında somut olarak var olanın nasıl bir araya geleceği probleminin ne derece büyük bir temsili olduğunun altı çizilmek istenmiştir.

Her örnek için, sağlık yapıları iç mekanlarına dair teorik olarak yanlış yapılmış bir içerik söz konusu değildir. Her bir örnek kendi başına değerlendirilebilecek yetkinliktedir. 2 farklı genel mekanın kendi aralarında farklı şekilde tasarlandığı örnekler odağında, uygulamacı yaklaşımın farklı örneklerine dikkat çekilmiştir. Bu durum temelinde, sağlık yapıları iç mekan tasarımı özelinde birincil olarak fikir geliştirmenin, gözlem ve araştırmanın önemini göstermektedir. Nesnelerin kimin için, nasıl ve ne şekilde bir araya gelerek kullanıcısı olan kişi/kişiler için ait hissetmeyi mümkün kılan mekanlar yaratabileceği sorularının cevabı, uygulama aşamasının gücünü ortaya koymasına destek sunmaktadır.

Günümüzde sağlık yapıları iç mekanlarında, yeni yapılması planlanan ve değişiklik gerektiren uygulamalar için ihale yoluyla intiyaçların listelenmesi ve fiyat performansı en verimli görülen tasarımcı/müteahhit/işveren tarafından sonuçlandırılması beklenmektedir. İhtiyaçların somut olarak ifadeye dökülmesi gerekliliği ile, mekan yaratım işi kaç metrekare zemin malzemesi, kaç sandalye veya hangi boyutta doğramadan kaç adet vb. malzeme ve elemanın olacağına dair bilgilerine dayanmaktadır. Mekansal gereksinimlerin listelenmesinin en yaygın yolu olarak bu yöntem kullanılmaktadır. Maalesef belirtilen durum insan-mekan etkileşimi dışında çok sayıda parametre barındırmaktadır. Ancak yarın için bu sistemin alternatifinin ne olacağı bilinmemektedir. Bu noktada, tasarımcıya düşen görev, kuramsal altığı ile uygulama pratiklerini beraber düşünerek mekan yaratma çabası içerisinde bulunma gerekliliğini unutmaması yönündedir. İç mekan tasarımı, yaratıcı uygulamalarla pek çok ortak noktası olan disiplinlerarası bir etkinliktir. Başka birçok konuda sınırlayıcı olan kurallar ve limitlerle engellenmeyen bir etkinliktir (Brooker ve Stone, 2011, s.27).

\section{KAYNAKLAR}

Bektaş, Cengiz, Mimarlıkta Eleştiri, 2. Basım, Literatür Yayıncılık, İstanbul, 2001, s.13.

Bielefeld, Bert ve Khouli, Sebastian El, Adım Adım Tasarım Fikirleri, çev. Volkan Atmaca, 2. Basım, Yapı-Endüstri Merkezi Yayınları, İstanbul, 2001, s.8,9.

Brooker, Graeme ve Stone, Sally, İç Mekan Tasarımı Nedir?, Çeviri: Zeynep Yazıcıoğlu Halu, Birinci Basım, Yapı-Endüstri Merkezi Yayınları, İstanbul, 2011, s.27.

Fawcett, Peter, Architecture Design Notebook, Second Edition, Architectural Press, Oxford, 2003, s.10-19.

Frederick, Matthew, 101 Things I Learned in Architecture School, First Edition, The Mit Press, Cambridge, 2007, s.10,65. 
Gay, Peter, Modernizm Sapkınlığın Cazibesi, çev. Sibel Erduman, 1. Basım, Everest Yayınları, İstanbul, 2017, s.57-67.

Hasol, Doğan, Ansiklopedik Mimarlık Sözlüğü, 10. Basım, Yem Yayın, İstanbul, 2008, s.313.

Kaptan, Burak Buğru, 20. Yüzyıldaki Toplumsal Değişimler Paralelinde İç Mekan Tasarımı Eğitiminin Gelişimi, 1. Basım, Anadolu Üniversitesi Güzel Sanatlar Fakültesi Yayınları, Eskişehir, 2003, s.1.

Lefebvre, Henri,(1995). The Production of Space, Translated by Donald Nicholson Smith. 4th Edition, Blackwell, Oxford, 1995,s.3-6.

Özkan, Ayşen, Günümüz Türk İç Mekan Tasarımcıları ve Tasarım Anlayışları İç Mekan Tasarımı Kuram ve Yöntemleri Işığında Bir Yaklaşım, 1. Basım, Lambert Academic Publishing, Germany, 2017, s.3-10.

Sözen, Metin ve Tanyeli, Uğur, Sanat Kavramlar ve Terimler Sözlüğü, 18. Basım, Remzi Kitabevi,, İstanbul, 2018, s.203.

\section{Internet Kaynakları}

${ }^{1}$ TDK'ya ait Türk Dil Kurumu Sözlükleri, Güncel Türkçe Sözlük'ten tanıma 12.03.2020 tarihinde ulaşılmıştır. https://sozluk.gov.tr/.

URL 1: https://pacific33architects.com/newsfeed-classic-full-springboro.html, Erişim Tarihi: 10.12.2019.

URL 2: memorial.com.tr, Erişim Tarihi: 05.12.2019.

URL 3: boex.co.uk, Erişim Tarihi: 08.12.2019.

\section{Görsel Kaynaklar}

Görsel 1. "When elements or spaces are not explicit but are nonetheless apparent-we can see them even though we can't see them-they are said to be implied." Frederick, M. (2007). 101 Things I Learned İn Architecture School, First Edition, Cambridge: The Mit Press, s. 10.

Görsel 2. "The most effective, most creative problem solvers engage in a process of meta-thinking, or "thinking about the thinking." Frederick, M. (2007). 101 Things I Learned İn Architecture School, First Edition, Cambridge: The Mit Press, s. 65.

Görsel 3. Tasarım Haritası, Bielefeld, B. ve Khouli, S. (2011). Adım Adım Tasarım Fikirleri, çev. isim, Basım, İstanbul: Yapı-Endüstri Merkezi Yayınları, s.8.

Görsel 4. Ankara'da bir hastane acil birimi, kayıt kabul bankosu ve bekleme alanları (Kişisel Arşiv, 2019).

Görsel 5. Kettering Opens Health Clinic Bekleme Alanı, https://pacific33architects.com/newsfeed-classic-full-springboro.html, Erişim Tarihi: 10.12.2019.

Görsel 6. İstanbul'da özel bir hastane, memorial.com.tr, Erişim Tarihi: 05.12.2019. 
Görsel 7. Ankara'da bir hastane çocuk yatan hasta birimi ve aynı birime ait çocuk oyun odası (Kişisel Arşiv, 2019).

Görsel 8. Royal Children Hospital oyun odası, Avustralya (Kişisel Arşiv,2017).

Görsel 9. The Royal United Hospital Neonatal Intensive Care Unit (NICU), Ingiltere, boex.co.uk, Erişim Tarihi: 08.12.2019. 